Jurnal Bidan Cerdas
e-ISSN: 2654-9352 dan p-ISSN: 2715-9965
Volume 3 Nomor 3, 2021
DOI: $10.33860 / j b c . v 3 i 3.458$
Website: http://jurnal.poltekkespalu.ac.id/JBC
Penerbit: Poltekk Kemenkes Palu

\title{
Hubungan Usia, Tingkat Pengetahuan, dan Riwayat Penggunaan Alat Kontrasepsi dengan Pemilihan Alat Kontrasepsi pada Penderita HIV/AIDS
}

\author{
Susanti凶, Sujianti, Yogi Andhi Lestari \\ STIKES Al-Irsyad Al-Islamiyyah Cilacap \\ Email korespondensi: santimahbub04@gmail.com
}

\section{ARTICLE INFO \\ Article History:}

Received: 2021-07-08

Accepted: 2021-08-16

Published: 2021-08-31

Kata Kunci:

Usia;

Pengetahuan;

Riwayat penggunan alat kontrasepsi;

Alat kontrasepsi.

\section{Keywords:}

Age;

Knowledge;

History of Contraceptive Use;

Contraceptive Devices.

\begin{abstract}
ABSTRAK
Pendahuluan: Pada pasangan yang salah satunya terdiagnosa HIV umumnya pasangan ditegaskan untuk tidak melakukan hubungan seks tanpa kondom. Termasuk pemilihan metode kontrasepsi pada perempuan dengan HIV/AIDS untuk mencapai tujuan reproduksi mereka. Tujuan penelitian ini adala untuk menganalisis hubungan usia, tingkat pendidikan, dan riwayat penggunaan lat kontrasepsi dengan pilihan metode kontrasepsi pada wanita dengan HIV/AIDS. Metode: Penelitian ini menggunakan rancangan deskriptif korelatif menggunakan analisis Fisher test dengan jumlah sampel yang memenuhi kriteria sebanyak 20 orang. Hasil: hubungan antara usia dengan penggunaan alat kontrasepsi sekarang dengan nilai $p \quad 0,241$, riwayat penggunaan alat kontrasepsi dengan penggunaan alat kontrasepsi sekarang dengan nilai $p 1,00$, dan tingkat pengetahuan dengan penggunan alat kontrasepsi sekarang dengan nilai $p$ 0,122 . Kesimpulan: tidak ada hubungan antara usia, riwayat penggunaan alat kontrasepsi tingkat pengetahuan, dan dengan penggunan alat kontrasepsi sekarang dengan nilai $p>0,05$.
\end{abstract}

\section{ABSTRACT}

Introduction: In couples, one of whom is diagnosed with HIV, generally the partner is emphasized not to have unprotected sex. This includes the selection of contraceptive methods for women with HIV/AIDS to achieve their reproductive goals. Objective: to analyze the relationship between age, education level, and history of contraceptive use with the choice of contraceptive method in women with HIV/AIDS. Methods: This study uses a descriptive correlative design using Fisher test analysis with a total sample of 20 people who meet the criteria. Results: the relationship between age and current contraceptive use with a $p$ value of 0.241 , a history of contraceptive use and current contraceptive use with a $p$ value of 1.00 , and the level of knowledge with current contraceptive use with a $p$ value of 0.122 . Conclusion: there is no relationship between age, history of contraceptive use, level of knowledge, and current use of contraceptives with $p$-value> 0.05 .

2021 by the authors. Submitted for possible open access publication under the terms and conditions of the Creative Commons Attribution (CC BY SA) license (https://creativecommons.org/licenses/by-sa/4.0/). 


\section{PENDAHULUAN}

Masalah yang berkembang sehubungan dengan penyakit infeksi HIV/AIDS adalah angka kejadian dan kematian tinggi. Diperkirakan ada 37,7 juta $(30,2-45,1$ juta) orang yang hidup dengan HIV pada akhir tahun 2020, lebih dari dua pertiganya (25,4 juta) berada di Wilayah Afrika (World Health Organization, 2021). Prevalensi pada wanita muda tetap berisiko terinfeksi HIV yang sangat tinggi. Di Afrika timur dan selatan, perempuan muda (usia15-24tahun) menyumbang $26 \%$ infeksi HIV baru, di Afrika bagian barat dan tengah dan Karibia masing-masing menyumbang $22 \%$ dan 17\% infeksi HIV (Kosgei et al., 2011). Transmisi HIV masih tetap berlangsung hingga kini,16.000 jiwa terinfeksi baru setiap harinya (Nasrorudin, 2012). Terjadi peningkatan jumlah pasien rawat jalan di Klinik VCT RSUD Cilacap setiap tahun. Pasien HIV pada tahun 2013 berjumlah 86 orang, tahun 2016 berjumlah 90 orang, dan tahun 2017 berjumlah 58 orang. Jumlah ibu hamil dengan HIV tahun 2012 sejumlah 3 orang dan meningkat signifikan pada tahun 2017 menjadi 18 orang. Hasil penelitian Susanti (2017) karakteristik penderita HIV/AIDS terbanyak pada umur 25-49 tahun sebesar $74 \%$, status perkawinan didapatkan data terbanyak sudah menikah sebesar $67.1 \%$, transmisi penularannya terbanyak adalah melalui lain-lain sebesar 40,1\%.Transmisi HIV masuk dalam tubuh manusia melalui tiga cara, yaitu: dari ibu terinfeksi HIV ke bayi, melalui hubungan seksual, dan kontak antar darah yang terinfeksi (Nasrorudin, 2012).

Mother to Child Transmission (PMTCT) dimana layanan ini terdiri dari 4 (empat) strategi, pertama mencegah penularan HIV pada perempuan usia reproduktif, kedua mencegah kehamilan yang tidak direncanakan pada ibu HIV, ketiga mencegah terjadinya penularan HIV dari ibu hamil HIV positif ke bayi yang dikandungnya dan keempat memberikan dukungan psikologis, social dan perawatan kepada ibu HIV positif beserta bayi dan keluarga (Kak et al., 2010; The Partnership for Maternal \& Child Health, 2010). Salah satu risiko kejadian kehamilan pada perempuan HIV adalah kehamilan yang tidak direncanakan/ unwanted pregnancy. Penyebab terjadinya unwanted pregnancy karena hubungan seks dini,berganti-ganti pasangan seks dan pasangan yang tidak tahu tentang status yang terkena HIV/AIDS (Kancheva Landolt et al., 2011).

Perempuan dengan HIV positif selain menggunakan kontrasepsi untuk mencegah terjadinya unwanted pregnancy, mereka juga perlu menggunakan double protection agar tidak menularkan kepada pasangannya, Penggunaan kondom pria secara konsisten telah terbukti mengurangi penularan HIV secara horisontal hingga $80 \%$. Kontrasepsi hormonal dapat meningkatkan risiko penularan HIV pada wanita berisiko tinggi seperti pekerja seks komersial, namun tidak pada wanita dengan risiko HIV rendah (Heikinheimo \& Lahteenmaki, 2008).

Infeksi HIV/AIDS sampai saat ini belum ditemukan obat dan vaksin (Dinas Kesehatan Propinsi Jawa Tengah, 2015). Jika perempuan yang masih dalam usia produktif manderita HIV/AIDS akan meningkatkan risiko penularan vertical kepada bayi. Penularan dari ibu ke janin saat ini menjadi penyebab kedua terbesar di dunia terjadinya penularan penyakit HIV(Hladik et al., 2009).Kontrasepsi merupakan komponen utama PMTCT yang berguna untuk perempuan dan laki-laki yang menderita HIV positif. Pemilihan kontrasepsi pada perempuan dengan HIV/AIDS memerlukan konseling untuk meningkatkan kesehatan reproduksinya secara komprehensif dan yang paling penting kontrasepsi pada penderita HIV adalah untuk mencegah penularan virus HIV dari ibu ke janin serta penularan kepada pasangan seksualnya. Hal ini didukung penelitian yang dilakukan oleh Susanti \& Widyoningsih 
bahwa responden menggunakan kontrasepsi "double protection" (Susanti \& Widyoningsih, 2018). Tujuan penelitian ini untuk menganalisis hubungan usia, tingkat pendidikan, dan riwayat penggunaan alat kontrasepsi dengan pemilihan metode kontrasepsi pada PUS dengan HIV AIDS.

\section{METODE PENELITIAN}

Rancangan penelitian ini adalah deskriptif korelatif untuk menganalisis faktor yang berhubungan dengan pilihan alat kontrasepsi yang dibgunakan oleh WUS dengan HIV/AIDS. Populasi dalam penelitian ini adalah seluruh WUS dengan HIV/AIDS yang periksa di RSUD Cilacap tahun 2020 dengan jumlah sampel 20 orang yang memenuhi kriteria, pernah hamil atau keguguran dengan teknik pengambilan sampel menggunakan purposive sampling. Variabel dalam penelitian adalah variabel independen karakteristik responden yaitu usia dengan kriteria risiko usia kurang dari 20 tahun dan lebih dari 35 tahun, riwayat penggunaan alat kontrasepsi yaitu KB dan Tidak KB, dan tingkat pengetahuan dan variabel dependen adalah penggunakan alat kontrasepsi yaitu satu alat kontrasepsi adalah responden hanya menggunakan satu alat kontrasepsi, double protection adalah responden menggunakan dua alat kontrasepsi selain menggunakan alat kontrasepsi modern juga ditambah dengan penggunaan kondom. Penelitian ini menggunakan data primer yang diperoleh langsung dari subyek penelitian, dengan kuesioner dengan 14 pertanyaan benar salah dan hasil ukur baik dan kurang baik dengan menggunakan analisis Fisher test.

\section{HASIL PENELITIAN}

Tabel 1 Karakteristik, Pengetahuan, dan Penggunaan Kontrasepsi Responden

\begin{tabular}{lrc}
\hline \multicolumn{1}{c}{ Variabel } & Frekuensi & Presentase (\%) \\
\hline Usia Ibu & & \\
$20-25$ tahun & 11 & 55,0 \\
$\quad$ 35 tahun & 9 & 45,0 \\
\hline Pendidikan & & \\
SD-SMP/sederajat & 18 & 90,0 \\
SMA & 2 & 10,0 \\
\hline Pekerjaan & & \\
IRT & 19 & 95,0 \\
Lain-lain & 1 & 5,0 \\
\hline Riwayat alkon & & \\
Kondom & 7 & 35,0 \\
Hormon & 6 & 30,0 \\
IUD & 2 & 10,0 \\
Doube protection & 4 & 20,0 \\
$\quad$ Tidak KB & 1 & 5,0 \\
\hline Pengetahuan & & \\
Baik & 7 & 35,0 \\
$\quad$ Kurang & 13 & 65,0 \\
\hline Alkon yang dipakai & & \\
Kondom & 12 & 60,0 \\
IUD & 2 & 10,0 \\
Doube protection & 6 & 30,0 \\
\hline
\end{tabular}


Tabel 1, dari 20 wanita dengan HIV/AIDS mayoritas usia 20-35 tahun dengan jumlah 11 orang $(55 \%)$, pendidikan terbanyak adalah SD-SMPdengan jumlah 18 orang (90\%). Pekerjaan mayoritas adalah IRT sebanyak 19 orang (95\%), riwayat penggunaan alat kontrasepsi paling banyak adalah kondom sebanyak 7 orang (35\%) dan terdapat 1 orang yang tidak menggunakan KB. Tingkat pengetahuan ibu tentang alat kontrasepsi sebagai pencegahan penularan karena HIV/AIDS yang mayoritas memiliki pengetahuan kurang sebanyak 13 orang (65\%), dan baik sebanyak 7 orang (35\%). Penggunaan alat kontrasepsi pada ibu dengan HIV/AIDS mayoritas menggunakan alat kontrasepsi kondom sebanyak 12 orang (60\%) sedangkan double protection hanya $30 \%$.

Tabel 2. Hubungan Usia, riwayat penggunaan alat kontrasepsi, dan tingkat pengetahuan ibu dengan pemilihan metode kontrasepsi pada PUS dengan HIV AIDS

\begin{tabular}{|c|c|c|c|c|c|}
\hline \multirow{3}{*}{ Variabel } & \multicolumn{4}{|c|}{ Penggunan Alat Kontrasepsi Sekarang } & \multirow{3}{*}{ Nilai $p$} \\
\hline & \multicolumn{2}{|c|}{ Satu alat kontrasepsi } & \multicolumn{2}{|c|}{ Double Protection } & \\
\hline & $\mathrm{n}$ & $\%$ & $\mathrm{n}$ & $\%$ & \\
\hline \multicolumn{6}{|l|}{ Usia } \\
\hline Berisiko & 9 & 75,0 & 3 & 25,0 & \multirow{2}{*}{0,241} \\
\hline Tidak Berisiko & 5 & 62,5 & 3 & 37,5 & \\
\hline \multicolumn{6}{|l|}{ Riwayat Penggunaan Alkon } \\
\hline Menggunakan KB & 13 & 68,4 & 6 & 31,6 & \multirow{2}{*}{1,000} \\
\hline Tidak mengqunakan KB & 1 & 100,0 & 0 & 0,0 & \\
\hline \multicolumn{6}{|l|}{ Tingkat Pengetahuan } \\
\hline Baik & 4 & 57.1 & 3 & 42.9 & \multirow{2}{*}{0,122} \\
\hline Kurang & 10 & 77,0 & 3 & 23,0 & \\
\hline
\end{tabular}

Berdasarkan tabel 2 bahwa usia berisiko lebih banyak yaitu 12 orang dengan terbanyak penggunaan alat kontrasepsi saat ini adalah menggunakan hanya satu alat kontrasepsi sebanyai 9 orang $(75 \%)$ dan menggunakan double protection sebanyak 3 orang $(25 \%)$. Dan usia yang tidak berisiko sama terbanyak hanya menggunakan satu alat kontrasepsi sebanyak 5 orang $(62.5 \%)$ dan 3 orang (37.5\%) mengunakan double protection Hasil uji analisis Fisher's exact test tidak terdapat hubungan antara usia ibu dengan pemilihan metode kontrasepsi antara usia ibu yang berisiko, tidak berisiko dengan pemilihan alat kontrasepsi dengan 1 alat kontrasepsi dan double protection dengan nilai 0.241 .

Riwayat penggunaan alat kontrasepsi adalah ibu terbanyak menggunakan alat kontrasepsi diantaranya adalah kondom, hormonal (pil, suntik, impalan) dan IUD sebanyak 19 orang dengan dengan terbanyak penggunaan alat kontrasepsi saat ini adalah satu alat kontrasepsi sebanyak 13 orang $(68.4 \%)$ dan yang memiliki riwayat tidak menggunakan KB sebanyak 1 orang sekarang ibu menggunakan satu alat kontrasepsi. Berdasarkan hasil analisis Fisher's exact test tidak terdapat hubungan antara riwayat alat kontrasepsi yang digunakan dengan pemilihan metode kontrasepsi antara dengan nilai 1.000

Tingkat pengetahuan responden tentang alat kontrasepsi mayoritas responden terbanyak adalah kurang sebanyak 10 orang $(77 \%)$ dengan mengunakan satu alat kontrasepsi dan yang menggunakan KB double protection sebanyak 3 orang $(23 \%)$, sedangkan yang memiliki tingkat pengetahuan baik sebanyak 4 orang $(57.1 \%)$ dengan menggunakan satu alat kontrasepsi dan sebanyak 3 orang menggunakan double protection sebanyak 3 orang (42.9\%). Berdasarkan hasil analisis Fisher's exact test 
tidak terdapat hubungan antara tingkat pengetahuan ibu penularan HIV/AIDS dengan pemilihan metode kontrasepsi antara dengan nilai 0.122 .

\section{PEMBAHASAN}

Hubungan usia ibu dengan pemilihan metode kontrasepsi padaPUS dengan HIV AIDS, berdasarkan hasil analisis Fisher's exact test tidak terdapat hubungan antara usia ibu dengan pemilihan metode kontrasepsi antara usia ibu yang berisiko, tidak berisiko dengan pemilihan alat kontrasepsi dengan 1 alat kontrasepsi dan double protection dengan nilai 0.241 . Berdasarkan hasil penelitian Susanti bahwa usia lebih dari 30 tahun memerlukan penggunaan alat kotrasepsi untuk menghindari penularan HIV/AIDS (Susanti, 2017). Hubungan riwayat penggunaan alat kontrasepsi dengan pemilihan alat kontrasepsi pada PUS dengan HIV/AIDS, berdasarkan hasil analisis Fisher's exact test tidak terdapat hubungan antara riwayat alat kontrasepsi yang digunakan dengan pemilihan metode kontrasepsi antara dengan nilai 1,000.

Pentingnya layanan KB dalam perawatan HIV/AIDS untuk mencegah kehamilan, mengurangi epidemi HIV dan meningkatkan kesehatan wanita. Wanita dengan HIV/AIDS menggunakan alat kontrasepsi untuk mengurangi adanya kehamilan yang tidak diinginkan (Akelo et al., 2013; Goldie et al., 2010; Wapmuk et al., 2018). Alat kontrasepsi IUD dilaporkan menjadi metode kontrasepsi yang paling umum digunakan pada pasien HIV. Kehamilan yang tidak diinginkan relatif umum terjadi pada wanita dengan praktik kontrasepsi yang rendah. Penggunaan kontrasepsi ganda harus dianjurkan untuk perempuan HIV-positif untuk melindungi kehamilan yang tidak diinginkan dan membatasi penularan HIV (Mersha et al., 2019).

Hubungan tingkat pengetahuan ibu dengan pemilihan metode kontrasepsi pada PUS dengan HIV AIDS, berdasarkan hasil analisis Fisher's exact test tidak terdapat hubungan antara tingkat pengetahuan ibu penularan HIV/AIDS dengan pemilihan metode kontrasepsi antara responden yang memiliki tingkat pengetahuan baik dan kurang dengan penggunaan alat kontrasepsi dengan nilai 0.122 . Hasil penelitian bahwa pengetahuan tentang kontrasepsi serta kebutuhan kontrasepsi di antara perempuan HIV-positif menjadi hal yang penting sehingga dianjurkan menggunakan alat kontrasepsi ganda (double protection) untuk menghindari penularan HIV/AIDS (Nkwabong et al., 2015). Didukung juga oleh penelitian Adedimeji, bahwa tingkat pengetahuan yang rendah tentang pentingnya kontrasepsi bagi perempuan HIV mengakibatkan mereka tidak menggunakan kontrasepsi (Adedimeji et al., 2012). Para wanita yang hidup dengan HIV untuk waktu yang lama lebih cenderung menggunakan alat kontrasepsi dibandingkan dengan wanita yang baru didiagnosis. Ini karena wanita yang hidup dengan HIV untuk waktu yang lama mungkin telah stabil hidup dalam masyarakat mereka dan menjadi aktif secara seksual (Gelaw et al., 2015; Schackman et al., 2008).

\section{SIMPULAN DAN SARAN}

Tidak ada hubungan antara usia, riwayat penggunaan alat kontrasepsi, dan tingkat pengetahuan dengan penggunaan alat kontrasepsi sekarang pada wanita usia subur dengan HIV/AIDS. Perlu adanya standar asuhan kebidanan pelayanan Keluarga Berencana pada wanita dengan HIV/AIDS.

\section{UCAPAN TERIMA KASIH}

Peneliti menyampaikan terima kasih kepada STIKES Al Irsyad Al Islamiyyah Cilacap yang telah memfasilitasi dan memberikan dukungan untuk terlaksananya kegiatan penelitian ini. 


\section{DAFTAR PUSTAKA}

Adedimeji, A., Abboud, N., Merdekios, B., \& Shiferaw, M. (2012). A Qualitative Study of Barriers to Effectiveness of Interventions to Prevent Mother-to-Child Transmission of HIV in Arba Minch, Ethiopia. International Journal of Population Research, 2012, 1-7. https://doi.org/10.1155/2012/532154

Akelo, V., Girde, S., Borkowf, C. B., Angira, F., Achola, K., Lando, R., Mills, L. A., Thomas, T. K., \& Lee Lecher, S. (2013). Attitudes toward Family Planning among HIV-Positive Pregnant Women Enrolled in a Prevention of Mother-To-Child Transmission Study in Kisumu, Kenya. PLoS ONE, 8(8), e66593. https://doi.org/10.1371/journal.pone.0066593

Dinas Kesehatan Propinsi Jawa Tengah. (2015). Data/Informasi Kesehatan Provinsi Jawa Tengah Pusat.

Gelaw, Y. A., Senbete, G. H., Adane, A. A., \& Alene, K. A. (2015). Determinants of late presentation to HIV/AIDS care in Southern Tigray Zone, Northern Ethiopia: an institution based case-control study. AIDS Research and Therapy, 12(1), 40. https://doi.org/10.1186/s12981-015-0079-2

Goldie, S. J., Sweet, S., Carvalho, N., Natchu, U. C. M., \& Hu, D. (2010). Alternative Strategies to Reduce Maternal Mortality in India: A Cost-Effectiveness Analysis. PLoS Medicine, 7(4), e1000264. https://doi.org/10.1371/journal.pmed.1000264

Heikinheimo, O., \& Lahteenmaki, P. (2008). Contraception and HIV infection in women. Human Reproduction Update, 15(2), 165-176. https://doi.org/10.1093/humupd/dmn049

Hladik, W., Stover, J., Esiru, G., Harper, M., \& Tappero, J. (2009). The Contribution of Family Planning towards the Prevention of Vertical HIV Transmission in Uganda. PLOS ONE, 4(11), e7691. https://doi.org/10.1371/journal.pone.0007691

Kak, L., Chitsike, I., Luo, C., \& Rollins, N. (2010). Prevention of mother-to-child transmission of HIV / AIDS programmes. In Opportunities for Africa's Newborns (pp. 113-126). https://www.who.int/pmnch/media/publications/aonsectionlll_7.pdf

Kancheva Landolt, N. T., Lakhonphon, S., \& Ananworanich, J. (2011). Contraception in HIVpositive female adolescents. AIDS Research and Therapy, 8(1), 19. https://doi.org/10.1186/1742-6405-8-19

Kosgei, R. J., Lubano, K. M., Shen, C., Wools-Kaloustian, K. K., Musick, B. S., Siika, A. M., Mabeya, H., Carter, E. J., Mwangi, A., \& Kiarie, J. (2011). Impact of Integrated Family Planning and HIV Care Services on Contraceptive Use and Pregnancy Outcomes. JAIDS Journal of Acquired Immune Deficiency Syndromes, 58(5), e121-e126. https://doi.org/10.1097/QAl.0b013e318237ca80

Mersha, A. G., Erku, D. A., Belachew, S. A., Ayele, A. A., Gebresillassie, B. M., \& Abegaz, T. M. (2019). Contraceptive use among HIV-positive and negative women: implication to end unintended pregnancy. Contraception and Reproductive Medicine, 4(1), 1-8. https://doi.org/10.1186/s40834-019-0084-2

Nasrorudin. (2012). Pendekatan Biologis Molekuler, Klinis dan Sosial HIV \& AIDS. Airlangga University Press. http://ailis.lib.unair.ac.id/opac/detail-opac?id=69758

Nkwabong, E., Minda, V., \& Fomulu, J. N. (2015). Knowledge, attitudes and practices of contraception by HIV positive women followed in a Cameroon region with high illiteracy rate: a cross sectional study. Pan African Medical Journal, 20, 1-6. https://doi.org/10.11604/pamj.2015.20.143.5252

Schackman, B. R., Dastur, Z., Ni, Q., Callahan, M. A., Berger, J., \& Rubin, D. S. (2008). Sexually Active HIV-Positive Patients Frequently Report Never Using Condoms in Audio Computer-Assisted Self-Interviews Conducted at Routine Clinical Visits. AIDS Patient Care and STDs, 22(2), 123-129. https://doi.org/10.1089/apc.2007.0037

Susanti. (2017). Karakteristik Penderita HIV/AIDS Di Klinik Vct Rumah Sakit Umum Daerah Cilacap Tahun 2013-2016. Viva Medika: Jurnal Kesehatan, Kebidanan Dan Keperawatan, 10(2), 20-27. https://ejournal.uhb.ac.id/index.php/VM/article/view/363

Susanti, \& Widyoningsih. (2018). Study fenomenologis pemilihan alat kontrasepsi pada wanita usia subur penderita HIV/AIDS. Medisain Jurnal IImiah IImu-IImu Kesehatan, 16(3), 107113. https://doi.org/10.30595/medisains.v16i3.3495 
The Partnership for Maternal \& Child Health. (2010). Opportunities for Africa 's Newborns. Partnership for Maternal, Newborn \& Child Health (PMNCH). https://www.who.int/pmnch/media/publications/oanfullreport.pdf

Wapmuk, A. E., Ezechi, O. C., Gbajabiamila, T., \& Ohihoin, A. (2018). Family Planning In The Context Of HIV Infection. Nigerian Journal of Clinical \& Biomedical Research, 7(9), 6-22. https://www.researchgate.net/publication/325255707_Family_Planning_In_The_Context Of_HIV_Infection

World Health Organization. (2021). HIV/AIDS. Who.Int. https://www.who.int/news-room/factsheets/detail/hiv-aids 